\author{
Aleksandra Grabowska-Powaga \\ University of Economics in Katowice \\ e-mail: aleksandra.grabowska@ue.katowice.pl \\ ORCID: 0000-0003-1694-6469
}

\title{
THE ROLE OF SOCIAL CAPITAL IN ECONOMIC ACTIVITIES IN POLAND IN THE PERIOD OF GLOBAL CRISIS
}

DOI: $10.15611 / \mathrm{pn} .2020 .7 .03$

JEL Classification: D02, D8, G01

(C) 2020 Aleksandra Grabowska-Powaga

This work is licensed under the Creative Commons Attribution-ShareAlike 4.0 International License. To view a copy of this license, visit http://creativecommons.org/licenses/by-sa/4.0/

Quote as: Grabowska-Powaga, A. (2020). The role of social capital in economic activities in Poland in the period of global crisis. Prace Naukowe Uniwersytetu Ekonomicznego we Wroctawiu, 64(7).

\begin{abstract}
Social capital is one of the factors which influence economic activities. According to Bourdieu (1986) social capital is the aggregate of the actual or potential resources which are linked to the possession of a durable network of more or less institutionalized relationships of mutual acquaintance and recognition - or in other words, to membership of a group - which provides each of its members with the support of the collectively owned capital, a 'credential' which entitles them to credit, in the various senses of the word. This influences the ability among the market entities to cooperate with each other and to create their competitiveness on this market. In the present global crisis caused by the coronavirus pandemic (COVID-19), social capital is gaining new meaning. Bottom-up initiatives of local communities that support especially small entrepreneurs and provide temporary continuity of management processes are becoming the basis for cooperation. The emerging social capital can become a remedy combating the social fears of a lack of rational operations in management processes in times of uncertainty at individual and community level. On the basis of the above premise, the main purpose of this paper is to identify the general role of social capital in the management of entities in the period of uncertainty caused by the pandemic based on the example of Poland. The paper consists of theoretical background and empirical part using the methods of critical analysis of the literature and desk research.
\end{abstract}

Keywords: economy, economic activities, social capital, crisis. 


\section{Introduction}

In the period of the global crisis caused by the coronavirus pandemic (SARS-CoV-2), many business activities were paralyzed by institutional defence mechanisms introduced by the countries (the suspension of stationary business activities and the implementation of tools for the remote functioning of entities in many business sectors). It is difficult to estimate the consequences of the transition of economies to stand-by mode during the next few months or years. All market players face anxiety, but it seems that micro and small enterprises may experience most severely the consequences of the suspension of business activity in the near future. The system solutions proposed by governments do not guarantee the continuity of business processes in the long term; they are only a certain tool to alleviate social tensions. In times of disinformation regarding the spreading pandemic and the socio-economic uncertainty associated with it, the local community is increasingly more often providing help to entrepreneurs. In many cases, the bottom-up initiatives of citizens temporarily help maintain, to at least a small degree, the continuity of business activity conducted by local entrepreneurs. Initiatives to support healthcare services, local food sector, and retail trade disseminated through messengers on social networking sites are becoming an increasingly frequent symbol of solidarity and civic help. The offered help and cooperation between residents and entrepreneurs, consequently leads to the strengthening of local social capital. In this age of uncertainty and crises it can become an antidote to the fears accompanying all individuals on every existential level, and help to survive one of the most difficult periods in the history of modern civilization.

The main cognitive aim of this article is to identify the general role of social capital in supporting economic activities in times of global crisis using the example of Poland. The research methods used in this article are critical literature analysis and desk research.

The main hypothesis of this article claims that local citizens' solidarity and support for entrepreneurs lead to cooperation, which is the basis for social capital.

\section{Social capital - institutional background}

The literature of the subject presents institutions as the "rules of the game in society, the structure of which shapes human interactions (interpersonal exchange) and has an impact on the situation of the economy in a given time" (North, 1990, p. 3). The efficiency of the rules of behaviour depends on certain institutional patterns adopted in a given community. Polanyi (2010) presented the mutuality principle and the principle of redistribution as the basis for behaviour patterns. Mutuality provides benefits to all entities involved in relationships network and ensures the smooth operation of market processes (production, exchange, consumption). 
On the other hand, redistribution represents the system of warehousing and storage of goods and constitutes the basis for the system of labour division, international trade, system of taxes and stock creation (Polanyi, 2010, pp. 58-59). According to North, "Institutions are the rules of the game in a society or more formally, the humanly devised constraints that shape human interaction" (North, 1990, p.3). A few years later the author specified the definition of institutions: "they are made up of formal constraints (e.g. rules, laws, constitutions), informal constraints (e.g. norms of behaviour, conventions, self-imposed codes of conduct), and their enforcement characteristics. Together they define the incentive structure of societies and specifically economies" (North, 1993, p. 3). In the literature, authors present two types of institutions, formal and informal ones. Institutions are not only formal legal rules, but also trust or unwritten principles, customs and rules which are widely observed and practiced in a social group. Informal institution are not such commonly known components of institutional structure as formal institutions. Informal institutions which are mentioned here are strongly ingrained in society's consciousness and this is why it takes so long to change them (unlike formal institutions). Nevertheless, informal institutions can be changed and have an impact on the functioning of the whole of society and economy. Informal institutions are often transformed into formal institutions to improve the functioning of society. Institutions can directly and indirectly influence economic activity on each market (in this case also the labour market) and economic growth. When talking about direct influence, one thinks of some economic incentives which are introduced by institutions, such as a growth or drop in production's dynamics or turnover, which impact on income and economic growth. Indirectly, the institutions can lead to growing investment, better management in different conflicts, better politics and social capital growth in society. Both formal and informal institutions help entities to take decisions concerning for example economic activity, or they allow the entities to achieve their planned goals. It is important that institutions should be treated not only as certain constraints but also as possibilities.

The dynamic and unpredictable changes occurring in contemporary economies force business entities to adapt to revolving market conditions. Contrary to many classical economic theories (Schumpeter, 1960, pp. 1-228) the entities cannot operate absolutely rationally in real economic systems. Their rationality in market behaviour is limited by many factors. The character of information streams that reach them is one of these factors. Information asymmetry and the dynamic nature of information streams bring unwillingness to take a risk. Therefore, they choose safe behaviour compliant with some routine that they acquire through the procedural repetition of the behaviour of the entities that proved to be successful, or through one based on the vision of how other entities would behave. Modelling behaviour based on the experiences of other entities or on the images of this behaviour can prove ineffective or even impossible. In the face of risk and the inability to repeat 'verified market behaviour', the entities aim at the establishment of relationships that often result 
in starting cooperation with other entities. The establishment of the relationships between entities often has an informal nature. Social capital is one of the informal institutions that emerged on the basis of the established relationships and is made up of the behaviour of entities, small groups forming networks of interaction and social institutions (Ostrom, 2005, p. 275). Due to the specific nature and the diversity of determinants shaping social capital, defining it in an explicit way is difficult. The literature on the subject provides a broad scope of the very interpretations of the analysed concept. However, the chronological history of the notion of social capital proves that it is a dynamically developing concept (cf. Table 1)

Table 1. Selected definitions of social capital

\begin{tabular}{|c|c|c|}
\hline Author(s) & Year & Definition \\
\hline P. Bourdieu & 1986 & $\begin{array}{l}\text { "The aggregate of the actual or potential resources which are linked to possession of } \\
\text { a durable network of more or less institutionalized relationships of mutual acquain- } \\
\text { tance or recognition or, in other words, with membership in the group that provides } \\
\text { every member support in the form of capital possessed by the group, and reliability } \\
\text { that offers them access to the credit in the broadest meaning of the word". }\end{array}$ \\
\hline R. Putnam & 1995 & $\begin{array}{l}\text { "Social capital refers here to such features of social organization as networks, norms, } \\
\text { and social trust that may improve society's efficiency while facilitating coordinated } \\
\text { operations. Just like other forms of capital, social capital is productive because it } \\
\text { enables attainment of some goals that might not be attained if there were lack of it } \\
{[\ldots] \text { For example if a group, the members of which show that they are trustworthy }} \\
\text { and trust others, will be able to achieve much more than a comparable group in which } \\
\text { there is no trust [...] Spontaneous cooperation is easier thanks to social capital". }\end{array}$ \\
\hline J.S. Coleman & 1998 & $\begin{array}{l}\text { "Group of social entities that have two common elements: they all consist of some } \\
\text { aspect of social structure, and they facilitate certain actions of both the individuals } \\
\text { and the whole institutions within the structure. Just like other forms of capital, social } \\
\text { capital is productive - it enables implementation of some goals, the attainment of } \\
\text { which would not be possible in the situation of its absence". }\end{array}$ \\
\hline A. Portes & 1998 & $\begin{array}{l}\text { "Social capital is the ability of actors to secure benefits by virtue of membership in } \\
\text { social networks or other social structures". }\end{array}$ \\
\hline E. Ostrom & 2000 & $\begin{array}{l}\text { "Social capital is shared knowledge, understanding, norms, rules and expectations } \\
\text { towards interaction patterns that groups of individuals bring to returning activity". }\end{array}$ \\
\hline F. Fukuyama & 2001 & $\begin{array}{l}\text { "Social capital is an objectified, informal norm that promotes cooperation between } \\
\text { two entities or a larger group of them ... Social capital is essential for effective func- } \\
\text { tioning of contemporary economy and is a sine qua condition of stable liberal de- } \\
\text { mocracy". }\end{array}$ \\
\hline OECD & 2001 & $\begin{array}{l}\text { "All networks that share norms, values and agreements that enable cooperation in, } \\
\text { and between groups". }\end{array}$ \\
\hline $\begin{array}{l}\text { K. Scrivens, } \\
\text { C. Smith }\end{array}$ & 2013 & $\begin{array}{l}\text { "Social capital refers to productive value of social networks where productive cha- } \\
\text { racter is approached not only as (in a narrow meaning) production of market goods } \\
\text { and services, but also in a broader meaning, as a result of prosperity". }\end{array}$ \\
\hline
\end{tabular}

Source: own case study.

Considering the function of social capital, it is defined in various ways, i.e. as a specific attribute, a feature of social life and an informal norm (see Fukuyama, 
2001; Portes, 1998; Putnam, 1995), or as a whole of relational resources and even a social structure (see Bourdieu, 1986; Coleman, 1998). Analysing the indicated definitions, divergences regarding the role and tasks that social capital performs in the functioning of economic entities can also be noticed. Many authors describe it as a commitment, norms of reciprocity or more or less institutionalized expectations. On the other hand, others attribute to it the role of merging and patching dispersed structural holes in communities. However, this does not exclude that it can be done through specific institutionalized expectations.

To sum up, social capital can be understood as an aggregate of formal and informal institutions, which enables entities to cooperate with each other and to achieve common goals in conditions of limited information and uncertainty (Grabowska-Powaga, 2019, p. 116).

The presented definitions have one common feature: they all describe social capital as some kind of resource. Apart from traditional production factors such as land and work, and contemporary ones, e.g. knowledge and social capital, they are becoming an economic resource for entities in market processes. Together with human capital and organisational capital they form intellectual capital approached as human resources of entities in market processes.

The emergence of social capital is determined by a number of externalities. The more social capital, the more externalities, and the more positive externalities, the more benefits for the socio-economic development of a given community.

Among the consequences of the emergence of social capital indicated by the authors in the literature on the subject, the following should be emphasized:

- social capital is a determinant of development, progress, economic growth, as well as a condition of stable liberal democracy,

- social capital is a resource of an individual or a group, but it is also perceived as public good,

- social capital implies a number of economic benefits (including a reduction of the risk and transaction costs and impact on the reliability of contractors, which is often emphasized by the authors), and social benefits (such as increasing solidarity between economic entities, among others).

The consequences of the emergence of social capital imply both its positive and negative impact on management processes. Therefore, like any resource used in market processes, social capital has advantages (it increases the overall effectiveness and efficiency of the community, improves the achievement of the goals of the individual and the whole group, strengthens the sense of belonging, and promotes long-term cooperation) and disadvantages (it may allow the individual to run 'shady business activities' under the name of the common good, it may lead to the exclusion of an individual from outside the group in which the social capital emerged).

The expressions of the development or the lack of social capital in institutional terms have an elementary and additional character. Institutional manifestations of the elementary nature include trust, which implies a number of benefits resulting from 
its impact on the relations of individuals participating in the management processes. Confidence facilitates negotiations, shortens the investment process while extending investment contracts; it reduces transaction costs, contributes to the increase of contractors' reliability, reduces corruption and the abuse of public goods, as well as increases inter-group solidarity and social control over the actions of the authorities. This makes interactions and interpersonal relations easier.

Communicativeness, solidarity and ethics should be distinguished among the institutional manifestations, which are the result of the development of social capital.

On the other hand, the level of civil society and civic activity are the manifestations of social capital in a socio-economic approach.

\section{Social capital as an opportunity for business activities on local markets in Poland in the period of global crisis}

The nature of social capital in Poland has been described by many experts as passive and crawling, while its level was rather an expression of the survival and adaptation of individuals to new institutions (despite many years of transformation) arising on the ground of economic and political determinants. There is no doubt that the low level of social capital in Poland is a derivative of many determinants.

According to Sztompka, Poles are a society with a past. First of all, Poles' lack of confidence in each other and in the authorities was affected by history, which created a sense of uncertainty, confusion and lack of transparency. The lack of trust was also an implication of political transformations. The emergence of negative symptoms of transformations at the beginning of the transformation period, such as unemployment, inflation and recession, led to a depreciation of the level of social capital (Sztompka, 2007, p. 20).

In the period of global crisis, social capital in Poland is gaining new meaning. The gradual shaping and strengthening of relationships between local entities is increasingly visible in situations that often rescue the continuity of management processes. Organized civic initiatives like the mutual support of local entities, including residents' help for sellers, local food outlets, municipal hospitals and other health care centres are the expressions of the development and strengthening of bonds that form social capital. While using IT and digital tools (for example social networking sites like Facebook), their users take the initiative of financial support (ordering products from a local supplier) or material support (sewing masks, organizing sanitary equipment and providing food). Despite the failure of the institutional mechanisms proposed by the state, the presented initiatives often ensure the continuity of management processes (at least temporarily), and thus the security to entities that almost overnight have found themselves facing the situations that threaten their existence (cf. Table 2). 
Table 2. Selected examples of civic initiatives in Poland in times of crisis (COVID-19)

\begin{tabular}{|l|l|l|}
\hline \multicolumn{1}{|c|}{ Civic initiative } & \multicolumn{1}{|c|}{$\begin{array}{c}\text { Territorial } \\
\text { implementation }\end{array}$} & \multicolumn{1}{|c|}{ Description } \\
\hline Help for elderly people & The whole country & $\begin{array}{l}\text { Citizens help elderly people to exist in } \\
\text { the pandemic times (shopping, chatting, } \\
\text { managing documents etc.) }\end{array}$ \\
\hline Meals for elderly people & The whole country & $\begin{array}{l}\text { Citizens prepare and deliver food for } \\
\text { elderly people }\end{array}$ \\
\hline "We call for meals" & The whole country & $\begin{array}{l}\text { Citizens (especially people who run } \\
\text { restaurants) prepare meals for medical staff }\end{array}$ \\
\hline $\begin{array}{l}\text { Pasks for medical staff } \\
\text { in Cracow }\end{array}$ & The whole country & $\begin{array}{l}\text { Psychologists offer help to anybody free of } \\
\text { charge }\end{array}$ \\
\hline "Visible hand" & Cracow & $\begin{array}{l}\text { Citizens made protective clothing for } \\
\text { medical staff }\end{array}$ \\
\hline $\begin{array}{l}\text { Other initiatives on social media } \\
\text { like Facebook, Instagram etc. }\end{array}$ & The whole country & $\begin{array}{l}\text { Citizens help each other in different } \\
\text { problems of life in the times of COVID-19 }\end{array}$ \\
\hline $\begin{array}{l}\text { Civic initiatives to support local } \\
\text { entrepreneurs (local food outlets, local } \\
\text { small groceries, local florists, local sport } \\
\text { clubs, local gyms etc.) }\end{array}$ \\
\hline
\end{tabular}

Source: own case study.

The observed activities of entities in management processes in the period of uncertainty caused by the pandemic (COVID-19) allow at this stage of the preliminary research to identify the role of social capital.

First, the social capital emerging within cooperation seems to fill the gaps in inefficiently working institutional mechanisms. Malfunctioning mechanisms that secure society are often patched up with bottom-up initiatives of local communities.

Secondly, Poles have relatively easily established, and now maintain, relationships with entities that they are related to through family and friendly relations (binding capital). It has been more difficult for Poles to respond to the needs of the individuals they do not know and to establish relationships that in the future could result in cooperation. The weakness expressed in the inability to establish bridging relationships was one of the main reasons for the low level of social capital in Polish society. However, the uncertainty of individuals caused by the coronavirus pandemic has led to a new distribution of social capital in Poland, i.e. strengthening the bridging ties between the entities that have not been related before.

\section{Conclusion}

The emergence and formation of social capital have often been a response to the adversities of nature which the communities have had to struggle with. Climatic 
conditions, soil fertility and threats of natural disasters (including epidemics) enforced the priority for actions increasing the chances of survival.

The benefits of cooperation within local groups (small but gradually increasing in number) have strengthened the habits of establishing durable relationships that are not aimed at a temporary benefit. It can be stated that due to the fact that from the beginning of its existence until today, humanity has always been facing the pressure exerted by nature, thus social capital has been, and is going to be, a method of dealing with this pressure. Therefore, the conclusions of the presented considerations regarding the role of social capital can have interdisciplinary applications; they refer not only to the management processes, but to all human activity. This is based on the statement that groups cope with difficult conditions (environmental or economic), with the unpredictability regarding the availability of resources and the consequences of their exploitation more easily than individuals (Grabowska-Powaga, 2019, p. 240).

In response to the emerging question about the sources of rationality in management processes in times of uncertainty, the ability of individuals establishing relationships to constantly overcome barriers and cross borders in the process of adaptation to changing living conditions is often indicated. This ability is the foundation of the emerging social capital, one of the most important contemporary resources and sources of wealth of societies, as well as the management efficiency of entities.

Hence it can be assumed that for the entities, social capital is an antidote combating social anxieties against the deficiency of rational action in management processes in times of uncertainty caused by the COVID 2019 pandemic crisis.

To obtain the detailed answer about the role of social capital in economic activities in Poland in the period of global crisis, more evidence is needed, especially based on primary research, but the above premise and the presented examples allow to conclude that at this stage of analysis the main aim of this paper can be considered to have been achieved and the hypothesis was positively verified.

\section{References}

Bourdieu, P. (1986). The forms of capital. In J. G. Richardson (Ed.), Handbook of theory and research for the sociology of education. New York: Greenwood Press.

Coleman, J. S. (1998). Social capital in the creation of human capital, American Journal of Sociology, (94), a supplement.

Fukuyama, F. (2001). Social capital, civil society and development. Third Word Quarterly, (1).

Grabowska-Powaga, A. (2019). Kapitat spoteczny a gospodarowanie. Aspekty teoretyczne $i$ empiryczne. Warszawa: Wyd. CeDeWu.

North, D. (1990). Institutions, institutional change and economic performance. Cambridge: Cambridge University Press.

North, D. (1993). Institutions, institutional change and economic performance. Cambridge: Cambridge University Press.

OECD. (2001). The well-being of nations. The role of human and social capital. Paris: OECD Publishing. 
Ostrom, E. (2000). Social capital: a fad or a fundamental concept? In P. Dasgupta and I. Serageldin (Eds.), Social capital: a multifaceted perspective. Washington D.C.: The World Bank.

Ostrom, E. (2005). Understanding institutional diversity. Princeton-Oxford: Princeton University Press. Polanyi, K. (2010). Wielka transformacja. Polityczne i ekonomiczne źródła naszych czasów. Warszawa: PWN.

Portes, A. (1998). Social capital: its origins and applications in modern sociology. Annual Review of Sociology, 24.

Putnam R. (1995). Demokracja w działaniu. Tradycje obywatelskie we wspótczesnych Włoszech. Kraków: Znak.

Schumpeter, J. A. (1960). Teoria rozwoju gospodarczego. Warszawa: PWN.

Scrivens, K., and Smith C. (2013). Four interpretations of social capital: an agenda for measurement (OECD Statistics Working Paper No. 06). Paris: OECD Publishing.

Sztompka, P. (2007). Nie ufaj nikomu. Gazeta Wyborcza, (281).

\section{ROLA KAPITALU SPOLECZNEGO W PROCESACH GOSPODAROWANIA W POLSCE W DOBIE KRYZYSU GLOBALNEGO}

Streszczenie: Kapitał społeczny jest czynnikiem wpływającym na działania gospodarcze. Według Bourdieu (1990) jest zbiorem zasobów wiążących się z posiadaniem trwałej sieci mniej lub bardziej zinstytucjonalizowanych związków, które dostarczają jednostkom wsparcia w postaci kapitału posiadanego przez kolektyw. W dobie globalnego kryzysu wywołanego pandemią koronawirusa (COVID19) kapitał społeczny nabiera nowego znaczenia. Oddolne inicjatywy lokalnych społeczności, które pomagają, szczególnie małym przedsiębiorcom, i zapewniają doraźną ciągłość procesów gospodarowania, stają się podstawą do współpracy. Powstający kapitał społeczny może się stać antidotum na lęki społeczne związane $\mathrm{z}$ niedostatkiem racjonalnego działania $\mathrm{w}$ procesach gospodarowania $\mathrm{w}$ czasach niepewności. Celem artykułu jest określenie głównej roli kapitału społecznego w gospodarowaniu podmiotów w czasach niepewności wywołanej pandemią na przykładzie Polski. W opracowaniu wykorzystano metody krytycznej analizy literaturowej i desk research.

Słowa kluczowe: gospodarka, gospodarowanie, kapitał społeczny, kryzys. 